\section{Commentary: You like potato and I like potahto}

\author{
Christopher E. Mascio, MD
}

Zurakowski and Jonas ${ }^{1}$ highlight a controversy as they ponder re-emergence of the Blalock shunt as initial therapy for tetralogy of Fallot (TOF). The authors first discuss early mortality and data analytics. These are intertwined. Rumors abound that some programs "game the system." The authors point out that a tetralogy that receives a shunt and then months later a complete repair counts "twice" in the current system. However, some programs perform a shunt for a symptomatic neonatal TOF, not to game the system, but because they feel it gives the patient the best chance of survival at their institution. Not all programs have a dedicated cardiac intensive care unit full of doubleboarded intensivists. Also, all patients are not able to travel to larger, regional centers.

Teaching neonatal surgery is difficult in today's climate. The authors hit the mark with this discussion. It is incredibly challenging to take fellows through neonatal cases, and our specialty has morphed into one of completing the 1- or 2-year congenital heart surgery residency followed by (hopefully) employment with a colleague willing to mentor. An early primary TOF repair can be tricky, even for experienced surgeons.

The authors then discuss a Journal of the American College of Cardiology article comparing palliation followed by repair versus primary repair for TOF and point out myriad weaknesses. $^{2}$ These include the following: lack of surgeon author on the manuscript; overstating mortality benefit based on not much difference between the 2 groups; and excluding those without 2-year follow-up reveals no

\footnotetext{
From the Division of Pediatric Cardiothoracic Surgery, Children's Hospital of Philadelphia, and Perelman School of Medicine, University of Pennsylvania, Philadelphia, Pa.

Disclosures: The author reported clinical consultant, HeartWare/Medtronic.

The Journal policy requires editors and reviewers to disclose conflicts of interest and to decline handling or reviewing manuscripts for which they may have a conflict of interest. The editors and reviewers of this article have no conflicts of interest.

Received for publication April 4, 2020; revisions received April 4, 2020; accepted for publication April 6, 2020; available ahead of print April 20, 2020.

Address for reprints: Christopher E. Mascio, MD, Children's Hospital of Philadelphia, 3401 Civic Center Blvd - M875, Philadelphia, PA 19104 (E-mail: mascioc1@email.chop.edu).

J Thorac Cardiovasc Surg 2021;161:400-1

0022-5223/\$36.00

Copyright (c) 2020 by The American Association for Thoracic Surgery

https://doi.org/10.1016/j.jtcvs.2020.04.029
}

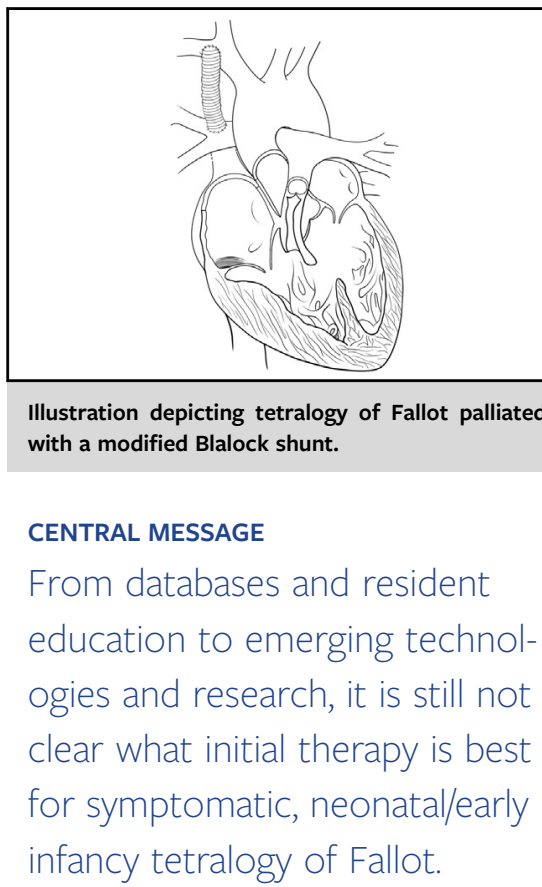

difference in 2-year mortality rates. Also, they highlight the lack of definition for TOF in the article. However, the same investigators evaluated their own experience, with a surgeon author, and found similar survival but increased morbidity with neonatal complete repair. ${ }^{3}$ And, I disagree that one manuscript will lead to a surge in palliative shunting of asymptomatic infants.

Patients today seem smaller and more complex, but I disagree that 2 to $2.5 \mathrm{~kg}$ is "robust." These patients often have poor tissue quality. Ductal stenting and infundibular stenting have changed the game for symptomatic TOF. The Congenital Catheterization Research Collaborative is investigating different methods of palliation. They compared ductal stenting with the Blalock in those with ductal dependent pulmonary blood flow and found no mortality difference. ${ }^{4}$ They plan to longitudinally examine all possible TOF interventions-initial palliation (Blalock, ductal stent, infundibular stent) followed by complete repair versus complete repair.

One area worth highlighting is that of neurologic/neurodevelopmental outcomes. There are many studies examining the brains and neurodevelopmental outcomes of patients with congenital heart disease. The data are mixed. Some examples include the following: volatile anesthetic agents having an association with worse neurodevelopmental outcomes ${ }^{5}$; too much focus on the cardiopulmonary bypass circuit, as coarctation via left thoracotomy and arch repair with cardiopulmonary bypass via sternotomy have similar rates of neurodevelopmental delay ${ }^{6}$; 
postponing complete repair negatively impacts brain growth and language development ${ }^{7}$; and patient factors may be more important than operative factors in predicting neurodevelopmental outcomes. ${ }^{8}$

I congratulate the authors on a timely, thought-provoking article.

\section{References}

1. Zurakowski D, Jonas RA. The many factors leading to resurgence of the Blalock shunt for tetralogy. J Thorac Cardiovasc Surg. 2021;161:396-9.

2. Savla JJ, Faerber JA, Huang YV, Zaoutis T, Goldmuntz E, Kawut SM, et al. 2-year outcomes after complete or staged procedure for tetralogy of Fallot in neonates. $J$ Am Coll Cardiol. 2019;74:1570-9.

3. Bailey J, Elci OU, Mascio CE, Mercer-Rosa L, Goldmuntz E. Staged versus complete repair in the symptomatic neonate with tetralogy of Fallot. Ann Thorac Surg. 2020;109:802-8
4. Glatz AC, Petit CJ, Goldstein BH, Kelleman MS, McCracken CE, McDonnell A, et al. Comparison between patent ductus arteriosus stent and modified BlalockTaussig shunt as palliation for infants with ductal-dependent pulmonary blood flow: insights from the Congenital Catheterization Research Collaborative. Circulation. 2018;137:589-601.

5. Diaz LK, Gaynor JW, Koh SJ, Ittenbach RF, Gerdes M, Bernbaum JC, et al. Increasing cumulative exposure to volatile anesthetic agents is associated with poorer neurodevelopmental outcomes in children with hypoplastic left heart syndrome. J Thorac Cardiovasc Surg. 2016;152:482-9.

6. Simon BV, Swartz MF, Orie JM, Adams HR, Seltzer LE, Angona RE, et al. Neurodevelopmental delay after the neonatal repair of coarctation and arch obstruction. Ann Thorac Surg. 2019;108:1416-22.

7. Lim JM, Porayette P, Marini D, Chau V, Au-Young SH, Saini A, et al. Associations between age at arterial switch operation, brain growth, and development in infants with transposition of the great arteries. Circulation. 2019; 139:2728-38

8. International Cardiac Collaborative on Neurodevelopment (ICCON) Investigators. Impact of operative and postoperative factors on neurodevelopmental outcomes after cardiac operations. Ann Thorac Surg. 2016;102:843-9.
See Article page 396.

\section{Commentary: Is there still a role for the systemic-to-pulmonary artery shunt in tetralogy?}

\author{
Harold M. Burkhart, MD, ${ }^{\mathrm{a}}$ Jess L. Thompson, MD, ${ }^{\mathrm{a}}$ \\ and Arshid Mir, MD
}

The surgical treatment of tetralogy of Fallot (TOF) remains a great success story with the introduction of a palliative systemic-to-pulmonary artery shunt by Drs Blalock, Thomas, and Taussig ${ }^{1}$ followed with complete surgical repair by Lillehei and colleagues. ${ }^{2}$ Now, more than 70 years after initial surgical repair, there continues to be considerable debate over the optimal timing of repair of this lesion.

\footnotetext{
From the ${ }^{\mathrm{a}}$ Division of Cardiovascular and Thoracic Surgery, and ${ }^{\mathrm{b}}$ Section of Pediatric Cardiology, University of Oklahoma Health Sciences Center, Oklahoma City, Okla.

Disclosures: The authors reported no conflicts of interest.

The Journal policy requires editors and reviewers to disclose conflicts of interest and to decline handling or reviewing manuscripts for which they may have a conflict of interest. The editors and reviewers of this article have no conflicts of interest.

Received for publication April 12, 2020; revisions received April 12, 2020; accepted for publication April 13, 2020; available ahead of print May 5, 2020.

Address for reprints: Harold M. Burkhart, MD, Division of Cardiovascular and Thoracic Surgery, University of Oklahoma Health Sciences Center, PO Box 26901, WP-2230, Oklahoma City, OK 73105 (E-mail: Harold-burkhart@ouhsc. edu).

J Thorac Cardiovasc Surg 2021;161:401-2

0022-5223/\$36.00

Copyright (c) 2020 by The American Association for Thoracic Surgery

https://doi.org/10.1016/j.jtcvs.2020.04.103
}

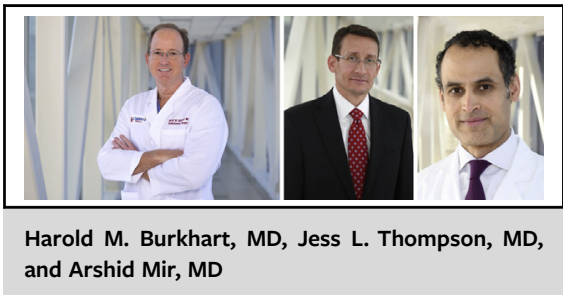

CENTRAL MESSAGE

Although most tetralogy infants are amenable to primary repair, there exists at-risk neonates who benefit from staged palliation followed by complete repair.

Although most centers agree with elective complete repair at the age of 3 to 6 months, the real controversy is what to do with the symptomatic neonate. Proponents of a 2-stage approach with neonatal palliation followed by complete repair cite benefits including increased somatic growth leading to a higher preservation of the pulmonary valve, avoidance of cardiopulmonary bypass and/or deep hypothermic circulatory arrest in the neonatal period, less risk of reoperation, lower rates of morbidity, and shorter length of hospital stay. ${ }^{3,4}$ 